\title{
Centrum integracji społecznej jako element ekonomii społecznej wspierający osoby uzależnione od alkoholu w ich powrocie na rynek pracy
}

Jeżeli chcesz zbudować okręt, to nie zwołuj ludzi w celu zrobienia planów, podzielenia pracy, przygotowania narzędzi i wycinania drzew, lecz naucz ich tęsknoty za bezmiarem morza. Wtedy zbudują statek sami.

Antonie de Saint-Exupery

Współczesny świat pomimo szybkiego rozwoju gospodarczego i technicznego, wpływającego na poziom życia współczesnych społeczeństw, nie uporał się z trapiącymi go problemami najbiedniejszych, wykluczonych i słabych. Ubóstwo, uzależnienia, przewlekłe bezrobocie, powiększająca się przepaść pomiędzy najbiedniejszymi i najbo-

$1 \quad$ Ks. dr Jan Klimek, Uniwersytet Papieski Jana Pawła II w Krakowie, Wydział Teologiczny, Katedra Psychologii Pastoralnej, od 2008 r. kapelan Szpitala Specjalistycznego im. dr. J. Babińskiego w Krakowie.

2 Mgr lic. Justyna Berlińska, doktorantka na Wydziale Teologicznym Instytutu Teologii Praktycznej Uniwersytetu Papieskiego Jana Pawła II w Krakowie. Zaangażowana w działalność duszpasterską dla pacjentów z problemami psychiatrycznymi Szpitala Specjalistycznego im. dr. Józefa Babińskiego w Krakowie. W latach 2014-2015 kierownik Centrum Integracji Społecznej w Krakowie utworzonego przez Stowarzyszenie Aktywizacji Społeczno-Cospodarczej Małopolskie Forum Pracy. 
gatszymi, stopniowy zanik klasy średniej trawią współczesny świat i coraz intensywniej domagają się interwencji „lepszej” części społeczeństwa. Podział na lepszych i gorszych jest coraz widoczniejszy i generuje coraz to nowe nierówności społeczne, gospodarcze i edukacyjne. Jedną z grup społecznie wykluczanych są osoby uzależnione od alkoholu, często bezrobotne, czasem też bezdomne. Jednak w otaczającym nas świecie trudno jest znaleźć sprawdzone działania mające na celu przeciwdziałaniu ich ubóstwu i bezrobociu.

Starając się sprostać dzisiejszemu tempu życia, społeczeństwo spodziewa się konkretnych i szybkich rezultatów w podejmowanych działaniach - również $\mathrm{w}$ tych podejmowanych wobec osób uzależnionych od alkoholu czy współuzależnionych. Oczekuje się, że osoby uzależnione po podjętej terapii i kilkutygodniowym pobycie na oddziale odwykowym odmienią swoje życie, znajdą pracę i uporają się z problemami. Rzeczywistość jednak nie jest dla nich tak łaskawa. Należy zaakcentować, że sama terapia dla osoby uzależnionej to dopiero pierwszy krok na drodze do trzeźwości. Osoba kończąca ją po kilkutygodniowej izolacji ze swojego dotychczasowego środowiska, jeśli chce skutecznie pokonać uzależnienie, musi dokonać bardzo dużych zmian - zastąpić dotychczasowe najbliższe otoczenie („kolegów od kieliszka") innym, znaleźć pracę, odbudować nadszarpnięte relacje z rodziną i przyjaciółmi. Jest to proces długi i wymagający wsparcia społecznego oraz różnych instytucji. Pośród tych osób, organizacji i inicjatyw znajdują się przedsięwzięcia z zakresu ekonomii społecznej, które często są nazywane dobrymi praktykami. Są to działania w wielu środowiskach, o różnym zasięgu i adresowane do różnych (choć bardzo konkretnych) grup społecznych. Podejmowane są z inicjatyw oddolnych (społeczność lokalna) lub odgórnych (państwowych). Jedną z takich inicjatyw są centra integracji społecznej jako jednostki edukacyjne, które mają skutecznie pomagać osobom uzależnionym (oczywiście nie tylko) w powrocie na rynek pracy. 


\section{Znaczenie pracy w życiu człowieka}

Wśród różnorakich działań pomocowych, które obecnie podejmowane są wobec osób cierpiących z powodu choroby alkoholowej oraz wobec współuzależnionych, istotne znaczenie mają te pomagające im powrócić na rynek pracy. W ten sposób nie tylko zmniejsza się koszty społeczne choroby alkoholowej ${ }^{3}$, ale wielu osobom borykającym się z problemem uzależnienia podaje się istotną formę wsparcia - przez zatrudnienie, które bardziej niż inne środki pomocowe ułatwia człowiekowi uzależnionemu reintegrację społeczną i zawodową oraz odbudowanie właściwego obrazu swojej osoby. Praca bowiem stanowi integralną część ludzkiej aktywności osobistej, zawodowej i społecznej. W encyklice Laborem exercens św. Jan Paweł II pisał:

Praca jest jednym $z$ tych aspektów, aspektem odwiecznym i pierwszoplanowym, zawsze aktualnym i wciąż na nowo domagającym się, by o niej myśleć i świadczyć. Coraz to nowe bowiem powstają pytania i problemy, coraz nowe rodzą się nadzieje, ale także obawy i zagrożenia, związane $\mathrm{z}$ tym podstawowym wymiarem ludzkiego bytowania, z którego życie człowieka jest zbudowane na co dzień, z którego czerpie właściwą sobie godność - ale w którym zawiera

3 Analiza kosztów świadczeń w zakresie leczenia uzależnienia od alkoholu i współuzależnienia, ponoszonych przez NFZ w latach 2012-2013: policzalne koszty medyczne związane z leczeniem uzależnienia od alkoholu i jego konsekwencji zdrowotnych z perspektywy publicznego płatnika w Polsce wyniosły 496994259 zł W 2012 oraz 514619247 zł w 2013. W ciągu roku nastąpił więc ich wzrost o 3,5 proc. Wartości te dotyczyły zidentyfikowanych kosztów leczenia uzależnienia od alkoholu, kosztów leczenia intoksykacji alkoholami, wybranych chorób wątroby, ostrego zapalenia trzustki oraz degeneracji układu nerwowego (por. M. Gałązka-Sobotka, Koszty ekonomiczno-społeczne zwiqzzane z leczeniem uzależnienia od alkoholu ijego konsekwencjizdrowotnych z perspektywy NFZ iZUS, http://orka.sejm.gov. pl/WydBAS.nsf/o/16ca3bc940d9cf61c1257d50003663c8/\$FILE/Koszty\%2oekonomiczno-społeczne.pdf (4.05.2016)). 
się zarazem nieustająca miara ludzkiego trudu, cierpienia, a także krzywdy i niesprawiedliwości, sięgających głęboko w życie społeczne w obrębie poszczególnych narodów i w zakresie międzynarodowym. (nr 1)

\section{Ekonomia społeczna}

Zagadnienie eko nomii społecznej w Europie swoją historią sięga XIX wieku. W tradycji jest związane $\mathrm{z}$ ruchem spółdzielczym rozwijającym się w większości państw europejskich. Od samego początku nie był to termin jednolicie rozumiany, podlegał zmianom w sposobach praktykowania oraz w zakresie pojęciowym. Lata dwudzieste poprzedniego wieku przyniosły dodatkowo koncepcję ekonomii solidarnościowej. Renesans problematyki ekonomii społecznej nastąpił w drugiej połowie XX wieku ${ }^{4}$.

Wieloaspektowe i wielowymiarowe pojęcie ekonomii społecznej nie zostało dotychczas sprecyzowane ${ }^{5}$. Jednak najczęściej oznacza działalność na pograniczu sektora prywatnego i publicznego prowadzoną przez organizacje $\mathrm{z}$ trzeciego sektora ${ }^{6}$. Warto zaznaczyć, że działania ekonomii społecznej nie mogą być zasilane jedynie odgórnymi działaniami instytucji państwowych, lecz muszą być zakorzenione w lokalnej społeczności i trapiących ją problemach

4 Por. B. Petrecka, U. Pietrzyk, Europejski model ekonomii społecznej-spojrzenie z perspektywy korzyści społecznych, „Zeszyty Naukowe Politechniki Rzeszowskiej” 2012 nr 286, s. 53 (Ekonomia i Nauki Humanistyczne, z. 19); Cospodarka społeczna i przedsiębiorstwo. Wprowadzenie do problematyki, red. E. Leś, Warszawa 2008.

5 Por. A. Cudowska-Sojko, Ekonomia społeczna a problem ubóstwa w Polsce, [w:] Ekonomia społeczna dla rozwoju społeczności lokalnych, red. A. Ejsmont, ]. Ruszewski, Suwałki 2013.

6 Trzeci sektor to sektor działalności non profit. To obszar funkcjonowania organizacji pozarządowych społeczeństwa obywatelskiego (por. U. Grzelońska, Rola sektora non profit w polskiej gospodarce, „Studia Ekonomiczne” 2011 nr 4, S. 236, 338). 
(mechanizmy ekonomii społecznej wykształcone organicznie). Ponieważ to otwarty segment gospodarki, najbardziej efektywne działania mają miejsce wówczas, gdy sprzyjają one spójności lokalnej społeczności i odgrywają wobec niej rolę integrującą. Gospodarka nie jest alternatywą wobec tego sektora, ale powinna być elementem komplementarnym, zdolnym do wspólnie podejmowanych działań i zależności ${ }^{7}$. Ekonomia społeczna ze wszystkimi jej komponentami nie może być substytutem gospodarki rynkowej, ale jednocześnie nie powinna być przez nią marginalizowana, ale stanowić jej ważny komponent i partnera wspólnie podejmowanych działań.

Niektóre definicje zwracają uwagę na to, iż ekonomia społeczna dotyczy działalności na pograniczu sektora prywatnego i publicznego, która jest prowadzona przez organizacje, w których dominuje prymat celów indywidualnych i społecznych nad kapitałem. Inni twierdzą, że ekonomia społeczna jest częścią gospodarki, w której przedsiębiorstwa są tworzone przez podmioty, które mają wspólne potrzeby i służą sobie nawzajem. Działanie tych podmiotów nie jest podporządkowane wyłącznie wskaźnikom ekonomicznym, a celami są przede wszystkim cele społeczne, między innymi pomoc wzajemna ${ }^{8}$.

Oczywiście zyski wypracowane z działalności gospodarczej muszą być przeznaczone na dalszą działalność i inicjatywy służące dobru wspólnemu. Bardzo ważny obszar działalności ekonomii społecznej stanowi przywracanie na rynek pracy osób bezrobotnych, niemogących odnaleźć się w jego dynamice, a także świadczenie pomocy dla osób zagrożonych ubóstwem i wykluczeniem społecznym.

Główne funkcje ekonomiczno-społeczne trzeciego sektora to: nauk. M. Frączek, J. Hausner, S. Mazur, Kraków 2012.

8 A. Cudowska-Sojko, Ekonomia społeczna a problem ubóstwa w Polsce, dz. cyt., s. 322. 
- zaspokajanie potrzeb społecznych na dobra publiczne, które nie są zaspokojone ani przez rynek, ani państwo, lub też są to potrzeby zaspokojone w niezadawalającym wymiarze;

- obniżanie kosztów dostarczania wybranych dóbr publicznych;

- zmniejszenie kosztów transakcyjnych niektórych dóbr prywatnych;

- zainicjowanie dyskusji społecznych i innowacyjności na wszystkich poziomach struktury społecznej;

- krytyka i blokowanie działań o wysokich negatywnych skutkach zewnętrznych;

- wskazywanie i wspieranie produkcji nowych dóbr publicznych, szczególnie tych o wysokich pozytywnych efektach zewnętrznych;

- społeczna kontrola funkcjonowania państwa i biznesu;

- socjalizacja obywatelska oraz przeciwdziałanie społecznej marginalizacji i ubóstwu? .

Ekonomia społeczna jako działalność gospodarcza kieruje się następującymi zasadami:

1. zasadniczym celem nie jest generowanie zysku i jego kapitalizacja;

2. dobrowolność uczestniczenia, zasadniczą podstawę uczestnictwa stanowi członkostwo, a tylko w szczególnych przypadkach stosunek zatrudnienia;

3. zarządzanie opiera się na demokratycznej zasadzie: jeden członek, jeden głos, albo zapewnia szeroką partycypację w procesach decyzyjnych;

4. dystrybucja dochodu ma na celu w pierwszym rzędzie zaspokajanie potrzeb społecznych czy pracowniczych, a akumulowany kapitał służy dalszemu rozwojowi działalności na rzecz zaspokojenia

9 Por. A. Cudowska-Sojko, Ekonomia społeczna a problem ubóstwa w Polsce, dz. cyt., S. 327. 
potrzeb społecznych. Jak już wspomniano, może ona przyjmować różne formy prawne i w większości wypadków jej głównym adresatem czy podmiotem są jednostki lub grupy społecznie defaworyzowane $^{10}$.

Szczególną rolą ekonomii społecznej jest budowanie przestrzeni, która umożliwi osobom wykluczonym powrót do społeczeństwa i pełnionych funkcji. Przestrzeni, w której dobro każdego człowieka będzie priorytetowe wobec maksymalizacji zysków ${ }^{11}$. Konkludując, wydaje się słusznym stwierdzenie że ekonomia społeczna to forma integracji społecznej, opierająca się na inicjatywach społeczeństwa obywatelskiego, które mają przywrócić aktywny sposób życia, szacunek i poczucie sprawiedliwości osobom zmarginalizowanym, wykluczonym społecznie, „zbędnym”. Jest to jednocześnie przestrzeń społeczna, gdzie zasady tolerancji, sprawiedliwości i równości regulują relacje pomiędzy jednostką i społeczeństwem ${ }^{12}$.

\section{Centrum integracji społecznej}

W Polsce centra integracji społecznej [dalej: CIS] stały się w ostatnich latach niezmiernie ważnym elementem polityki zatrudnienia, bowiem w przestrzeniach lokalnych, w sferze szeroko rozumianych usług społecznych, umożliwiają tworzenie nowych miejsc pracy oraz stosowanie elastycznych form zatrudnienia dla osób będących najtrudniejszą grupą klientów dla publicznych służb zatrudnienia ${ }^{13}$. Długotrwałe bezrobocie powoduje, że dotknięte nim osoby

Por. P. Sałustowicz, Pojęcie, koncepcje i funkcje ekonomii społecznej, [w:] Ekonomia społeczna. Perspektywa rynku pracy i pomocy społecznej, red. J. Staręga-Piasek, Warszawa 2007, s. 30 (Ex Libris Pracownika Socjalnego).

11 Por. Model inkubatora ekonomii społecznej, red. D. Binek, Nowy Sącz 2010, s. 7.

12 Por. P. Sałustowicz, Pojęcie, koncepcje i funkcje ekonomii społecznej, dz. cyt., s. 22.

13 Por. C. Miżejewski, Polityka społeczna wobec sektora ekonomii społecznej, Warszawa 2006 (Ekonomia Społeczna Teksty, 21). 
nie mają możliwości realizacji potrzeb związanych z samodzielnym i odpowiedzialnym funkcjonowaniem w strukturach społecznych, implikuje również zróżnicowane konsekwencje o charakterze psychospołecznym. Niska samoocena, frustracje, depresje, wycofanie spoleczne, postawy agresywne oraz inne destrukcyjne modele uczestnictwa w życiu zbiorowym są silnie związane $\mathrm{z}$ ograniczeniem lub całkowitym brakiem zdolności do podejmowania aktywności zawodowej. Wykorzystując fundamentalne zasady teorii aktywizacji sił społecznych, działania CIS-u koncentrują się wokół wykorzystania potencjału tkwiącego w społecznościach lokalnych. Pobudzanie do aktywności, rozbudzanie poczucia sprawstwa, przeciwdziałanie postawom roszczeniowym jest jednym $\mathrm{z}$ istotnych elementów oddziaływania skierowanego na budowanie postaw odpowiedzialności, kreatywności i podmiotowości wśród ludzi pozostających z różnych powodów na marginesie życia społecznego.

Zadaniem centrum integracji społecznej jest działanie na rzecz osób zagrożonych wykluczeniem społecznym. Działalność CIS-u ma przede wszystkim charakter edukacyjny. Podejmowana aktywność ma na celu poprawę funkcjonowania jednostki w dwóch zależnych od siebie sferach aktywności. Pierwsza to reintegracja społeczna, która oznacza wszystkie działania mające na celu odbudowanie i podtrzymanie u osoby uczestniczącej w zajęciach w CIS-ie umiejętności uczestniczenia w życiu społeczności lokalnej i odgrywania ról społecznych w miejscu pracy, zamieszkania lub pobytu. Druga sfera to reintegracja zawodowa, której działania skupiają się na odbudowaniu i podtrzymaniu u osoby uczestniczącej w zajęciach w CIS-ie zdolności do samodzielnego świadczenia pracy na rynku. Centrum, w ramach reintegracji zawodowej, może prowadzić działalność wytwórczą, handlową lub usługową (żaden rodzaj nie ma charakteru gospodarczego i może być prowadzony jako statutowa działalność odpłatna pożytku publicznego) oraz działalność wytwórczą w rolnictwie.

Według danych z Głównego Urzędu Statystycznego [dalej: GUS] pod koniec roku 2013 w Polsce było 127 CIS-ów, które aktywnie 
podejmowały swoją działalność (to o 35 więcej niż w roku 2012). Jak podają dane, większość z nich prowadziły organizacje z trzeciego sektora, zdecydowanie rzadziej jednostki samorządu terytorialnego i główne gminy ${ }^{14}$.

W 2013 r. odbiorcami działań centrów integracji społecznej było około 6,9 tys. osób z grup zagrożonych wykluczeniem społecznym. Najczęściej uczestnikami zajęć z zakresu integracji społecznej i zawodowej były osoby długotrwale bezrobotne - stanowiły one $69 \%$ wszystkich podopiecznych CIS-ów ${ }^{15}$.

Warto również zaznaczyć, że wśród 3,2 tysiąca osób, które zakończyły zajęcia w CIS-ie w roku 2013, prawie 40 proc. podjęło pracę zarobkową (to o 5 proc. więcej niż $\mathrm{w}$ roku poprzednim). W zdecydowanej wielkości osoby te znajdowały pracę poza CIS-em. Prowadzenie centrum to bardzo kosztowna forma działalności, całkowicie oparta na systemie dotacji ze środków publicznych, co wiąże się m.in. z tym, że ustawa bardzo szczegółowo reguluje funkcjonowanie i zasady uczestnictwa w tego typu jednostce ${ }^{16}$.

CIS jako forma prawna jest adresowane do organizacji, które zajmują się udzielaniem pomocy oraz wsparcia osobom zagrożonym wykluczeniem społecznym. Ważne, aby zakładając CIS, wziąć pod uwagę grupę docelowych uczestników, by pomysł odpowiadał na potrzeby społeczności lokalnej.

14 Por. Główny Urząd Statystyczny, Departament Badań Społecznych i Warunków Życia, Urząd Statystyczny w Krakowie, Centra integracji społecznej, zakłady aktywności zawodowej i warsztaty terapii zajęciowej w 2013 r. Notatka informacyjna, Warszawa 2014.

15 Cłówny Urząd Statystyczny, Departament Badań Społecznych i Warunków Życia, Urząd Statystyczny w Krakowie, Centra integracji społecznej..., dz. cyt.

16 Por. J. Kluczyńska, A. Sienicka, Centrum Integracji Społecznej-przedsiębiorstwo społeczne?, Warszawa 2008, s. 6 (Ekonomia Społeczna Teksty, 9). 
Ustawa o zatrudnieniu socjalnym wskazuje, że osoby zagrożone wykluczeniem społecznym to te, które ze względu na swoją sytuację życiową nie są w stanie własnym staraniem zaspokoić swoich podstawowych potrzeb życiowych i znajdują się w sytuacji powodującej ubóstwo oraz uniemożliwiającej lub ograniczającej uczestnictwo w życiu zawodowym, społecznym i rodzinnym. CIS może również realizować programy specjalne dla osób niepełnosprawnych i ubiegać się z tego tytułu o dofinansowanie z funduszu PFRON $^{17}$.

W grupie beneficjentów CIS-u ustawa w art. 1.2. wymienia następujące osoby:

- bezdomnych realizujących indywidualny program wychodzenia z bezdomności;

- uzależnionych od alkoholu, po zakończeniu terapii podstawowej;

- uzależnionych od narkotyków lub innych środków odurzających, po zakończeniu terapii;

- chorych psychicznie, w rozumieniu przepisów o ochronie zdrowia psychicznego;

- długotrwale bezrobotnych;

- opuszczających zakłady karne;

- uchodźców;

- osoby niepełnosprawne.

Według ustawy z dnia 13 czerwca 2003 roku o zatrudnieniu socjalnym (Dz.U. Nr 122 poz. 1143 z późn. zm., art. $3 \$ 2$ ) organem założycielskim dla CIS-u mogą być:

1. jednostki samorządu terytorialnego $\mathrm{w}$ formie:

a) jednostek budżetowych,

b) samorządowego zakładu budżetowego;

2. organizacje pozarządowe;

17 J. Kluczyńska, A. Sienicka, Centrum Integracji Społecznej-przedsiębiorstwo społeczne?, dz. cyt., s. 4. 
3. podmioty, o których mowa w art. 3 ust. 3 pkt 1 i 3 ustawy z dnia 24 kwietnia 2003 roku o działalności pożytku publicznego i o wolontariacie (Dz.U. z 2010 r. Nr 234 poz. 1536 oraz z 2011 r. Nr 112 poz. 654 i Nr 149 poz. 887), z zastrzeżeniem, że w przypadku spółdzielni socjalnych centrum mogą tworzyć spółdzielnie zakładane przez podmioty wspomniane w art. 4 ust. 2 pkt 2 i 3 ustawy z dnia 27 kwietnia 2006 roku o spółdzielniach socjalnych (Dz.U. Nr 94 poz. 651, z 2009 r. Nr 91 poz. 742 oraz z 2010 r. Nr 28 poz. 146) - zwane dalej „instytucjami tworzącymi”.

\section{Zasady}

Uczestnik dobrowolnie zgłasza swoją chęć udziału w CIS-ie, podpisując regulamin i zobowiązując się do przestrzegania go. Udział w CIS-ie rozpoczyna się w dniu podpisania indywidualnego programu zatrudnienia socjalnego [dalej: IPZS] na okres próbny. Od tego momentu uczestnikowi przysługuje zarówno pełnia praw, jak i obowiązków wynikających z regulaminu CIS-u. Uczestnik zajęć w centrum ma prawo do czterech dni płatnego urlopu wypoczynkowego na cały okres uczestnictwa, który w ustawie jest określany na 18 miesięcy. Dodatkowo uczestnicy mają możliwość wykorzystania 14 dni płatnego zwolnienia lekarskiego L4 na cały okres uczestnictwa, jednak więcej niż 14 dni L4 nie jest płatne. Każdy uczestnik zobowiązany jest do niezwłocznego poinformowania pracownika socjalnego o swojej niezdolności do pracy oraz do przedstawienia stosownego zaświadczenia dającego możliwość usprawiedliwienia dnia. Dzień taki uznaje się za dzień nieobecności usprawiedliwionej. Konieczność usprawiedliwiania nieobecności również reguluje ustawa, według której cztery dni nieobecności nieusprawiedliwionej w ciągu miesiąca powodują całkowitą utratę świadczenia w danym miesiącu. Uczestnik świadczy pracę pięć dni w tygodniu po minimum sześć godzin dziennie, jednak dokładny harmonogram zajęć jest ustalany według pracownika socjalnego i dopasowywany do 
indywidualnych możliwości i potrzeb każdej osoby biorącej udział w zajęciach CIS-u.

\section{Świadczenia}

Ustawa o zatrudnieniu socjalnym daje CIS-owi możliwość wypłacania uczestnikom szczególnej formy świadczeń zwanych świadczeniami integracyjnymi. Świadczenie integracyjne wypłaca się uczestnikom raz w miesiącu w wysokości:

- 80 proc. zasiłku dla bezrobotnych przez pierwszy miesiąc (brutto 430,70 zł, netto 397,71 zł), w tym składka na ubezpieczenie zdrowotne w wysokości 32,99 zł;

- 100 proc. zasiłku - podczas dalszego uczestnictwa (brutto 538,30 zł, netto 477,85 zł), w tym składka na ubezpieczenie zdrowotne w wysokości 48,45 zł.

Należy jednak pamiętać, że pomiędzy uczestnikiem zajęć a CIS-em nie ma stosunku pracy, a wypłacane świadczenia nie są wynagrodzeniami z tytułu umowy o pracę. Osoby, które uczestniczą w ofercie CIS-u, pozostają zarejestrowane w Grodzkim Urzędzie Pracy [dalej: GUP] jako osoby bezrobotne ${ }^{18}$. Środki wypłacane uczestnikom CIS-u pochodzą z Funduszu Pracy; zarówno świadczenia netto, jak i pochodne od nich nie pochodzą ze środków miejskich ośrodków pomocy społecznej [dalej: MOPS], mimo że uczestnicy są potencjalnymi klientami ośrodka pomocy społecznej.

\section{Uczestnicy}

Uczestnik trafia do centrum integracji społecznej na podstawie:

- wniosku własnego, wniosku zakładu lecznictwa odwykowego lub ośrodka pomocy społecznej; 
- organizacji pozarządowej lub klubu integracji społecznej, za zgodą tej osoby lub jej przedstawiciela ustawowego;

- wniosek podlega zaopiniowaniu przez pracownika socjalnego ośrodka pomocy społecznej właściwego dla miejsca zamieszkania osoby kierowanej;

- w przypadku osób uzależnionych, o których mowa w art. 1 ust. 1 pkt 2 i 3, warunkiem przyjęcia do centrum jest zakończenie programu psychoterapii w zakładzie lecznictwa odwykowego lub programu terapeutycznego w zakładzie opieki zdrowotnej.

Ścieżkę uczestnictwa, czyli IPZS, można podzielić na trzy okresy: próbny, właściwy i przedłużający uczestnictwo. Okres próbny trwa miesiąc - w tym czasie każdy uczestnik otrzymuje 50 proc. świadczeń. Właściwy okres zatrudnienia socjalnego trwa 11 miesięcy i wtedy uczestnik otrzymuje pełne świadczenie integracyjne oraz ma możliwość uzyskania premii, która stanowi równowartość maksymalnie 20 proc. otrzymywanego świadczenia. Uczestnik ma w tym czasie zapewniony posiłek lub jego ekwiwalent. Czas przedłużenia uczestnictwa jest ewentualny i trwa sześć miesięcy. W tym okresie uczestnikowi przysługuje pełne świadczenie integracyjne, premia oraz posiłek. Zaprzestanie realizacji IPZS może nastąpić w każdym momencie trwania programu w dwóch przypadkach - po pierwsze wtedy, gdy uczestnik uporczywie narusza postanowienia programu i opuszcza zajęcia, lub po drugie, gdy przedłoży on oświadczenie o odstąpieniu od realizacji programu.

IPZS powinien szczegółowo określać zakres i formy reintegracji zawodowej i społecznej uczestnika, zaznaczyć rodzaje sprawności psychofizycznych niezbędnych do podjęcia pracy oraz metody ich ćwiczenia. Ważne, aby każdy uczestnik znał osobę lub osoby odpowiedzialne za realizację tego programu.

Po zakończeniu określonego według ustawy o zatrudnieniu socjalnym okresu uczestnictwa w CIS-ie przewiduje ona trzy scenariusze dalszego wspierania zatrudnienia uczestnika programu: 
1. skierowanie uczestnika centrum do prywatnego pracodawcy i nawiązanie $\mathrm{z}$ uczestnikiem stosunku pracy na szczególnych zasadach zatrudnienia wspieranego;

2. podjęcie absolwenta CIS-u na pracownika (również na zasadach zatrudnienia wspieranego);

3. utworzenie spółdzielni socjalnej przez uczestników CIS-u po zakończeniu programu edukacyjnego.

\section{Centrum Integracji Społecznej w Krakowie}

Centrum Integracji Społecznej w Krakowie zostało powołane do istnienia przez Stowarzyszenie Aktywizacji Społeczno-Gospodarczej Małopolskie Forum Pracy w Krakowie. Wszelkie podejmowane przez Stowarzyszenie oraz jego partnerów działania mają za zadanie neutralizację skutków wykluczenia społecznego osób bezrobotnych, będących w szczególnie trudnej sytuacji na rynku pracy. Stowarzyszenie stawia sobie za cel zatrudnianie osób, których nawiązanie relacji z rynkiem pracy jest znacznie utrudnione. Stowarzyszenie interesują m.in. osoby o zdiagnozowanej chorobie alkoholowej, po odbyciu kary pozbawienia wolności, bezdomni, niewydolni społecznie, wychowawczo oraz osoby nieaktywne i wycofane.

Brak zintegrowanych działań adresowanych do wyżej określonych grup bezrobotnych skłonił Stowarzyszenie do nawiązania niezbędnej współpracy z innymi podmiotami gospodarczymi (kioski Ruchu, firmy utrzymujące czystość i konserwacji zieleni) w celu dostosowania oferty do potrzeb uczestników CIS-u. Zadaniem Stowarzyszenia jest skuteczne i racjonalne wykorzystanie zasobów istniejących w krakowskim środowisku organizacji wspierających bezrobotnych oraz jak największa skuteczność w kierowaniu pracowników po ukończeniu programu na otwarty rynek pracy.

Podstawą prawną do działalności CIS-u w Krakowie były następujące dokumenty: 
- ustawa z dnia 13 czerwca 2003 roku o zatrudnieniu socjalnym (Dz.U. Nr 122 poz. 1143 z późn. zm.);

- ustawa z dnia 19 grudnia 2008 roku o zmianie ustawy o promocji zatrudnienia i instytucjach rynku pracy oraz o zmianie niektórych innych ustaw;

- Strategia Rozwoju Województwa Małopolskiego na lata 2007-2013;

- Strategia Rozwoju Krakowa przyjęta uchwałą Nr 742/2550 Rady Miasta Krakowa z dnia 13 kwietnia 2005 roku.

Strukturę organizacyjną CIS-u w Krakowie przedstawia poniższy schemat:

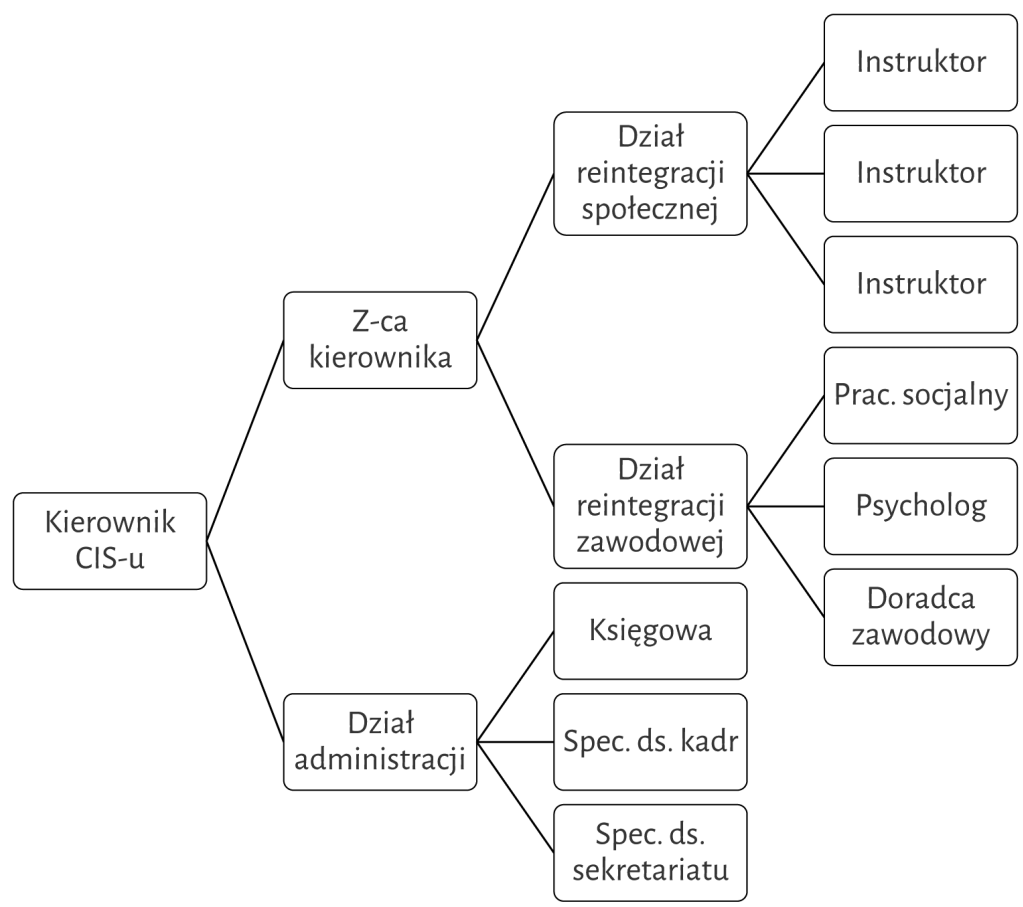


Droga uczestnika - indywidualny program zatrudnienia socjalnego

\section{Podpisanie indywidualnego programu zatrudnienia socjalnego na miesięczny okres próbny}

- Obowiązkowe szkolenie BHP, badania lekarskie

- Świadczenie pracy w określonym module. Udział w zajęciach z reintegracji społecznej. Konsultacje zpracownikiem socjalnym, psychologiem i doradcą zawodowym, weryfikowanie wzajemnych oczekiwań oraz wyznaczenie celów do dalszej realizacji

\section{Podpisanie indywidualnego programu zatrudnienia socjalnego po okresie próbnym na 11 miesięcy}

- Dalsze świadczenie pracy w określonym module, udział w zajęciach w ramach reintegracji społecznej

- Stałe konsultacje z pracownikiem socjalnym, doradca zawodowym oraz psychologiem

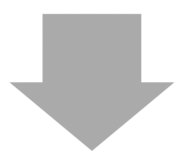

\section{Przedłużenie lub zakończenie współpracy}

- Jeżeli współpraca układa się pomyślnie oraz uczestnik realizuje postanowienia IPZS - podpisanie aneksu do IPZS na kolejny okres uczestnictwa. Docelowo maksymalny okres współpracy w ramach centrum wynosi 18 miesięcy.

W sytuacji, gdy uczestnik łamie regulamin CIS-u, nie wywiązuje się z zapisów IPZS - zakończenie współpracy

- Zakończenie współpracy możliwe jest na każdym etapie uczestnictwa w CIS-ie 
Uczestnicy Centrum otrzymywali nieodpłatnie jeden posiłek dziennie $\mathrm{w}$ trakcie pobytu, świadczenie integracyjne, premię motywacyjną, zwrot kosztów przejazdu. Dodatkowo mogli korzystać $\mathrm{z}$ indywidualnego poradnictwa psychologicznego, społecznego, zawodowego i prawnego. Działalność CIS-u wspierała uczestników poprzez dodatkowe zajęcia terapii uzależnień indywidualnej i grupowej, grupy wsparcia: AA, AN, AL-anon, Al-teen oraz grupy samopomocowe. Dodatkowo organizowane były warsztaty motywacyjne obejmujące zasady komunikacji społecznej, wzmacnianie samooceny i poczucia własnej wartości, umiejętność radzenia sobie ze stresem i przezwyciężania problemów życiowych, kształtowanie aktywnej i odpowiedzialnej postawy życiowej, wzmacnianie motywacji do aktywności zawodowej. Oprócz tego uczestnicy CIS-u mieli możliwość korzystania z wejściówek na spektakle i imprezy organizowane przez Centrum Kultury Rotunda w Krakowie, a każdy uczestnik po okresie próbnym mógł korzystać z Kasy Zapomogowej Samorządu Uczestników CIS-u. Uczestnicy mieli też możliwość korzystania z Banku Żywności.

Powody likwidacji CIS-u

CIS działający na terenie Szpitala Specjalistycznego im. dr. Józefa Babińskiego w Krakowie [dalej: Szpital] zakończył swoją działalność w 2015 roku. Powodów jego likwidacji było kilka, a jeden z nich stanowił brak współpracy, otwartości i zainteresowania Szpitala, a szczególnie Wojewódzkiego Ośrodka Terapii Uzależnień i Współuzależnień [dalej: WOTUW], który działał na terenie Szpitala (został zlikwidowany w lutym 2016). CIS chciał instytucjonalnie pomagać pacjentom kończącym terapię. Ścisła współpraca z WOTUW-em miała pomóc wejść pacjentom na rynek pracy poprzez mechanizm pomocowy CIS-u. Niestety do wspomnianej współpracy nigdy nie doszło, co można tłumaczyć trudnym okresem w działalności WOTUW-u, poprzedzającym jego zamknięcie, i restrukturyzacją w sposobie le- 
czenia osób uzależnionych w Szpitalu. Dodatkowo, pomimo wsparcia instytucjonalnego i chęci finansowania przez komisję alkoholową, nie udało się powołać klubu abstynenckiego, który miał działać na terenie Szpitala w ramach struktury CIS-u. W założeniach Szpital miał zaoferować konieczną infrastrukturę oraz umożliwić pacjentom kończącym terapię uczestnictwo. CIS z kolei miał zaoferować program pomocowy, wsparcie psychologiczne i socjalne oraz zająć się organizacją i realizacją projektu. Niestety nie doszło do jego rozwinięcia. Byłby on dużym wsparciem dla pacjentów kończących terapię, którzy po siedmiotygodniowym okresie spędzonym na oddziale stanęli przed koniecznością odnalezienia się w rzeczywistości społecznej.

Centrum Integracji Społecznej powołane przez Stowarzyszenie Aktywizacji Społeczno-Gospodarczej MFP.

Podsumowanie od 2009 do 2015. Mariusz Jachimczak

Utworzenie Centrum Integracji Społecznej wynikało z moich wcześniejszych, wieloletnich doświadczeń z tworzenia i prowadzenia szeregu programów reintegracji zawodowej. Od roku 2003 nieprzerwanie tworzyłem i prowadziłem programy zatrudnienia dedykowane grupom będącym w szczególnie trudnej sytuacji na rynku pracy. Były to: Specjalne Programy Zatrudnienia Romów, program zatrudnienia Romów w ramach Rządowego Programu na Rzecz Społeczności Romskiej oraz wielokrotnie prowadzone programy Robót Publicznych dla osób uzależnionych, po terapii, np. Program dla Wojewódzkiego Urzędu Pracy „Konserwator”.

Zgodnie z sugestią Dyrektora Andrzeja Martynuski z Wojewódzkiego Urzędu Pracy w roku 2007 podjąłem kroki w kierunku powołania Centrum Integracji Społecznej. Konsultując swój pomysł z właściwym Departamentem Ministerstwa Pracy i Polityki Społecznej, Regionalnym Ośrodkiem Polityki Społecznej w Krakowie, 
opracowałem niezbędne dokumenty, procedury i po złożeniu wniosku do Wojewody w maju 2008 uzyskałem status CIS.

Przywiązywałem dużą wagę do podnoszenia swoich kwalifikacji $\mathrm{w}$ pracy z osobami wykluczonymi, uzależnionymi i marginalizowanymi.

Lata 2009-2011

W lutym i marcu 2009 uprzedziłem Grodzki Urząd Pracy w Krakowie o zamiarze przyjmowania uczestników do CIS, zakładałem, że właściwe będzie uprzedzenie GUP, gdyż nieodzowne stanie się opracowanie procedur rozliczania i wypłacania świadczeń integracyjnych. Chciałem w ten sposób uniknąć nieporozumień lub przewlekłości rozliczeń, gdyż roczny proces tworzenia CIS już był wystarczająco kosztowny, a stowarzyszenie nie mogło sobie pozwolić na angażowanie własnych środków, gdyż ich nie posiadało.

W lipcu 2009 CIS przyjął pierwszych uczestników skierowanych z krakowskiego MOPS i po miesiącu z własnych środków dokonywał wypłaty świadczeń, licząc na szybką refundację z GUP. Niestety pierwsze refundacje wypłaconych od lipca świadczeń nastąpiły w listopadzie 2009. Kilka miesięcy CIS musiał wypłacać świadczenia $\mathrm{z}$ własnych lub pożyczanych środków. Wynikło to z narzuconych przez GUP procedur rozliczania świadczeń dopiero w październiku 2009.

Od lipca 2009 CIS otrzymywać miał dotacje na bieżące funkcjonowanie z Gminy Kraków (nie na świadczenia), jako zadanie zlecone przez krakowski MOPS. W ramach wsparcia dotacyjnego CIS powinien otrzymywać środki na funkcjonowanie, pokrywające wynagrodzenia pracowników (instruktorów zawodu, pracowników socjalnych, psychologów, doradcę zawodowego itp.), koszty zajęć, lokali i mediów, badań lekarskich uczestników, szkoleń BHP, codziennych posiłków dla uczestników itp. MOPS przyjął, że dotacja będzie wypłacana CIS jako refundacja poniesionych przez CIS wydatków. 
Kompletnie ignorując tryb wskazany w ustawie o zatrudnieniu socjalnym.

Podsumowując, obydwie kluczowe instytucje, tj. GUP i MOPS, przyjęły wobec CIS zasadę „swobodnego” podejścia do sytuacji CIS, nie rozumiejąc, jakie to może pociągnąć konsekwencje. W piśmie z czerwca 2006 informowałem dyrekcję MOPS o problemach i konsekwencjach niezgodnego z obowiązującymi procedurami finansowania CIS. Należy podkreślić, że miesięcznie kwota zobowiązań CIS wobec uczestników, pracowników i innych dostawców usług była zbliżona do kwoty około 60 ooo zł.

$\mathrm{Na}$ żadnym etapie tworzenia CIS nie deklarowałem posiadania takiej kwoty lub jej wielokrotności, nikt tego również nie oczekiwał. Kumulacja kwot wypłaconych przez CIS w pierwszych miesiącach znacząco przekraczała 60 ooo zł.

Wielokrotnie próbowałem wyjaśnić w MOPS, że ten tryb finansowania przez Gminę zadania pod nazwą Centrum Integracji Społecznej nigdzie w Polsce nie jest praktykowany. Taki stan trwał do maja 2010 roku, kiedy to MOPS rozpoczął kontrolę, wstrzymując tzw. dotację (czyli refundację wydatkowanych przez CIS środków). Szczególna „skrupulatność” pracowników MOPS polegała między innymi na tym, że kontrolujący po dniu spędzonym w CIS składał notatkę z wykazem pozycji do wyjaśnienia, informując, że odpowiedź ma być na rano dnia następnego. Najczęściej w ciągu dnia dzwonił, że przekładał termin wizyty na kiedy indziej, jeszcze to ustali. Taki stan trwał około dwa miesiące. I w tym okresie CIS nie otrzymywał nawet refundacji wydanych wcześniej kwot.

W związku z trudną współpracą z MOPS wystąpiłem do Ministerstwa Pracy i Polityki Społecznej z pismem o wykładnię, w jakim trybie CIS powinien otrzymywać dotacje. Pismo z MPIPS potwierdziło moje stanowisko, że „Przepis art. 10 ust 4 nie jest zasadą refundowania kosztów (wydatków) miesięcznych".

Jednak pierwsze miesiące działalności CIS w tak trudnej i niesprzyjającej atmosferze już wtedy wpłynęły niekorzystnie na działalność 
CIS. Powstało szereg niezamierzonych, dodatkowych kosztów, odsetki od nieterminowych wypłat, pochodnych od tych wypłat oraz innych płatności.

W lecie 2010 Pani Katarzyna Zapał - Dyrektor Zarządu Budynków Komunalnych w Krakowie, zwróciła się do mnie z pytaniem, czy możliwe byłoby opracowanie oferty dla mieszkańców z zaległościami czynszowymi wobec Gminy Kraków, gdyż „szef”, czyli Prezydent Krakowa, chciałby coś takiego zrobić. Możliwe działania przedstawiłem w liście do Pani Dyrektor. Jednocześnie na każdym kroku podkreślałem, że konieczna jest dobra współpraca i zaangażowanie wszystkich partnerów. Oczywiście byłem zapewniany o współpracy, dlatego też w listopadzie 2010 roku na wniosek ZBK zawarłem pierwsze umowy o pracę z osobami kierowanymi do odpracowania zadłużeń. Poinformowałem ZBK, że osoby te zawarły umowy o pracę i po mojej stronie jako pracodawcy jest częściowe, comiesięczne ponoszenie kosztów zatrudnienia. Nie biorąc pod uwagę innych kosztów związanych z tworzeniem miejsca pracy, narzędzi, badań lekarskich, szkoleń BHP, pomieszczeń, odzieży ochronnej oraz obsługi kadrowo-biurowej.

Wiosną 2011 w związku z sugestią dyrekcji ZBK złożyłem ofertę na wykonanie usług polegających na sprzątaniu śmieci, utraciłem 4000 wadium, gdyż nie miałem wszystkich koncesji na odpady, mimo próśb wadium nie udało się odzyskać. Jednak faktycznie w lipcu 2011 otrzymaliśmy pierwsze zlecenie z ZBK, podkreślić należy, że już w tym czasie wygasły umowy pierwszej grupy zadłużonych, zawarte w listopadzie 2010 (zatem zmuszony byłem dofinansować zatrudnienie każdej z tych osób, co nigdy nie zostało i nie zostanie to zwrócone). W następnych miesiącach ZBK zlecało nam różne prace, sowicie nakładając kary za złą jakość, przesunięcie terminu itp. Powierzając nam szereg zleceń, co do których wykonanie narażało nas na dodatkowe, wysokie koszty, np. wycinki trudnych drzew za abstrakcyjne stawki. Wydaje się, że w ZBK nikt chyba nie rozumiał, że osoby, z którymi mam wykonać te prace, to osoby z przypadku, 
często niechętne, uzależnione, bez kwalifikacji. Może w ZBK pracownikom brakowało wyobraźni. Mimo tych utrudnień w krótkim okresie prowadzenia programu dla mieszkańców spłacili oni Gminie Kraków około 320 ooo zł.

Oprócz pracowników w Robotach publicznych uczestnicy CIS byli również klientami programu, jednak ustawicznym problemem było urealnienie wysokości zaliczek otrzymywanych z GUP, ich wysokość z reguły istotnie odbiegała od wysokości koniecznych świadczeń. Taka sytuacja dodatkowo potęgowała problemy, gdyż terminy płatności świadczeń i terminy wypłaty wynagrodzeń pracownikom skierowanym z ZBK pokrywały się. Refundacja świadczeń z GUP następowała często po około dwóch miesiącach (ustawa o zatrudnieniu socjalnym dopuszcza refundacje nawet do trzech miesięcy), spiętrzając problemy z płynnością finansową. W załączeniu decyzje GUP o rozliczeniu zaliczki. Wnioskowana przez CIS kwota świadczeń za sierpień 2011 to 30 439,35 zł, przyznana zaliczka do tej kwoty 13 ooo, brakującą kwotę 17 439,35 uzupełnił CIS i otrzymał jej zwrot w październiku.

CIS dla Krakowa mógłby przynosić szereg korzyści, warte podkreślenia, że uczestnicy CIS (najczęściej klienci MOPS) otrzymują świadczenia integracyjne ze środków Funduszu Pracy, a nie gminy. Uczestnictwo w CIS całkowicie uwalnia Gminę z wypłaty świadczeń np. z pomocy społecznej. Nasi uczestnicy CIS wykonywali szereg prac na rzecz Gminy, przełożyli większość stopni na Kopiec Kościuszki od strony Alei Waszyngtona, wykonali ogród dla dzieci z Oddziału Hematologii Dziecięcej IP, prace te wykonano całkowicie nieodpłatnie.

Jednak wydaje się, że nikogo to w Krakowie nie interesowało. MOPS od samego początku był trudnym partnerem. Przejawem niezrozumiałej praktyki MOPS było utrudnianie i podrażanie pracy CIS, np. poprzez przesyłanie opinii o osobach, które mogły i chciały być uczestnikami CIS, jednak z zaznaczeniem, że nie jest to skierowanie do CIS, i kierowanie np. osoby, która nie mogła być uczestnikiem CIS (nie dopuszcza ustawa o zatrudnieniu socjalnym osób uzależnionych, 
przed terapią), z informacją, że kieruje do CIS. Przysparzało to niepotrzebnej pracy i kosztów.

W roku 2012 wystąpiłem do dyrekcji GUP z prośbą o urealnienia zaliczek na świadczenia integracyjne. Zaliczki na świadczenia daleko odbiegały od faktycznych kosztów świadczeń i pochodnych. Dodatkowo GUP miał prawo, i często z niego korzystał, do refundowania wypłaconych świadczeń nawet po dwóch miesiącach. Kiedy to CIS musiał dokonać następnej płatności.

Podsumowując, wielokrotnie informowałem MOPS, ZBK i GUP, że możliwe jest tworzenie wielu różnych programów wsparcia dla osób marginalizowanych lub będących w trudnej sytuacji, jednak przy pełnej, faktycznej współpracy, a nie deklaracjach bez pokrycia. Szczególny wkład w paraliż CIS ma krakowski MOPS. Wielokrotnie informowałem również, że CIS zagraża utrata płynności finansowej w przypadku dalszej tak niejasnej współpracy i takich utrudnień ze strony „partnerów”. Takiej ignorancji krakowskich urzędników wobec CIS nie mogłem się spodziewać.

Obecnie CIS nie ma ani jednego uczestnika. Stowarzyszenie ma obecnie szereg kwot niezrefundowanych z GUP. Wszystkie kwoty otrzymane z GUP jako zaliczki zostały w terminach wypłacone, jednak widząc, że współpraca mimo upływu lat nie staje się prostsza, słysząc od pracowników GUP na moją prośbę o szybsze refundowanie wypłaconych świadczeń, że mają trzy miesiące na ich refundacje (tak dopuszcza ustawa, ale nie realia, w których działał CIS), zaniechałem wnioskowania o zaliczki. Z przychodów stowarzyszenia stopniowo reguluję przeterminowane zobowiązania, chcąc po ich zebraniu złożyć łączny wniosek do GUP o ich zrefundowanie (GUP w otrzymanym piśmie ustalił, że refundacji może dokonać do trzech lat wstecz). Z ostatniej grupy uczestników pięć osób w lipcu 2014 zostało zatrudnionych w utworzonej przy udziale stowarzyszenia spółdzielni socjalnej, osoby te mają umowy o pracę i z tytułu zatrudnienia pobierają obecnie comiesięczne wynagrodzenie. Nie będę nadal angażował środków swoich i całej swojej rodziny, żeby 
wypłacać świadczenia integracyjne, krakowski model narzucony przez jednostki miejskie tego wymaga.

Podsumowując okres pięciu lat współpracy z krakowskimi jednostkami miejskimi, nie mam poczucia, że na etapie współpracy zostało naruszone prawo, mam jednak odczucie, że żadnej jednostce na budowaniu realnego partnerstwa nie zależało. Każda z tych jednostek sprowadzała się do minimum współpracy, nie widząc korzyści dla swojej jednostki czy mieszkańców Krakowa. Centrum Integracji Społecznej powinno być instytucją wsparcia dla osób z grup szczególnie trudnych do aktywizacji, centrum powinno czuć wsparcie i życzliwe partnerstwo. W krakowskich jednostkach miejskich niebezpiecznie jest szukać partnerstwa.

Kraków, 22 lutego 2015

Dokument otrzymali:

1. Ministerstwo Pracy i Polityki Społecznej, Departament Pomocy i Integracji Społecznej;

2. Andrzej Kulig, Pełnomocnik Prezydenta Miasta Krakowa ds. Polityki Społecznej;

3. Urząd Wojewódzki, Wydział Polityki Społecznej;

4. Bogusław Kośmider, Przewodniczący Rady Miasta Krakowa;

5. Instytut Rozwoju Służb Społecznych.

\section{Na zakończenie-dlaczego CIS?}

Dla każdego człowieka praca zawodowa ma fundamentalne znaczenie. Jeszcze bardziej temat ten staje się istotny w życiu osób, które z powodu choroby alkoholowej doświadczyły wielu deficytów. Ich samoocena jest zaniżona, a możliwość powrotu na rynek pracy o wiele trudniejsza niż u chorych somatycznie. Działalność CIS-u jest ważną pomocą we wprowadzeniu na rynek pracy i odzyskaniu właściwej samooceny, a tym samym i dobrostanu psychicznego. 
Poprzez aktywność zawodową człowiek na nowo odzyskuje własną godność, czuje się potrzebny i przestaje być beneficjentem instytucji pomocowych. W ten sposób najskuteczniej sam pomaga sobie. CIS ma mu pomóc w tej drodze.

Działalność CIS-u na terenie Szpitala Specjalistycznego im. dr. Józefa Babińskiego w Krakowie zakończyła się po dwóch latach istnienia. Zamknięcie tej instytucji należy postrzegać jako wielką stratę dla pacjentów oddziałów alkoholowych i zmarnowanie kolejnej realnej szansy pomocy dla nich. Nie szukając winnych, wskazać można na jedną podstawową przyczynę zamknięcia działalności - brak współpracy pomiędzy CIS-em, WOTUW-em i Szpitalem. Ten sam problem nakreślił w swoim piśmie Mariusz Jachimczak, prezes Stowarzyszenia Aktywizacji Społeczno-Gospodarczej Małopolskie Forum Pracy i pomysłodawca powołania CIS-u w Krakowie. W przejmujących słowach podkreślił brak współpracy i wsparcia ze strony instytucji pomocowych, które pomimo deklarowanego wsparcia i chęci współpracy ograniczały swoje działania do niezbędnego minimum, a to okazało się zbyt mało. Udzielanie nieadekwatnej pomocy i nieskuteczne działania są, szczególnie dla osób uzależnionych, gorsze niż niepodejmowanie żadnych działań. Ekonomia społeczna wciąż rozbija się o bariery instytucjonalne i brak wyobraźni miłosierdzia urzędników magistratu, GUP-u, MOPS-u itd. A przecież te instytucje powołano ostatecznie po to, by niosły pomoc i służyły najbardziej potrzebującym. 